\title{
REVIEW
}

\section{Plaque imaging: clinical implications and use of invasive methods}

\author{
Stanislav Tůma ${ }^{1}$, David Tesař ${ }^{2}$, Josef Veselka $^{3}$, Jiří Neuwirth ${ }^{2}$ \\ ${ }^{1}$ Institute of Radiology and Toxicology, Faculty of Health and Social Studies, University of South Bohemia \\ in České Budějovice, Czech Republic \\ ${ }^{2}$ Clinic of Imaging Methods, $2^{\text {nd }}$ Medical Faculty, Charles University, Prague, Czech Republic \\ ${ }^{3}$ Center of Cardiology and Cardiac Surgery, University Hospital Motol, Prague, Czech Republic
}

Received $5^{\text {th }}$ October 2007.

Revised $30^{\text {th }}$ December 2007.

Published online $10^{\text {th }}$ January 2008.

\begin{abstract}
Summary
The composition of artherosclerotic plaque can be distingushed from the normal physical properties of tissues by the inflammatory mediators and the cells' remodelling arterial walls, and can therefore be demonstrated by imaging methods. Imaging of the vulnerable atherosclerotic plaque is now accepted as the main target in the diagnostics of imminent acute complications in atherosclerosis. Recent results of clinical trials (Ross's, CAPTIM, Prague) suggest facilitated intervention - primary angioplasty together with pre-hospital fibrinolysis during transportation - as the urgent therapeutical method of choice. This life-saving emergency treatment is considered to be invasive because of the angiography and intravascular ultrasonography.

Angiography ranges from digital subtraction angiography to three-dimensional imaging, together for example with the rotational acquisition of angiographic pictures. X-ray densitometry of the atherosclerotic plaque tissues is also a promising method for differentiation. In contrast, intravascular ultrasonography, by the direct use of varying frequencies, allows the differentiation of tissues, and the demonstration of their relationship by virtual histology. The plaques liable to rupture (unstable vulnerable plaques) contain a large lipid core covered by a thin fibroplastic cap layer with a number of macrophages and mastocytes, and it seems that they, the plaques, can be identified by a so called new "gold-standard" modality. The usefulness of invasive methods is not only in distinguishing pathological processes or the location and size of the atherosclerotic plaque and its calcified parts, but in attracting attention to the extent of its vulnerability. The response to therapy of the arterial wall can also be demonstrated.
\end{abstract}

Keywords: atherosclerotic plaque - FDG-PET/CT - intravascular ultrasound - virtual histology - dualsource mutidetector-row CT - three-dimensional rotational angiography

Stanislav Tůma, Institute of Radiology and Toxicology, Faculty of Health and Social Studies, MEDIPOINT, Matice Školské 17, 37001 České Budějovice, Czech Republic

邑 sttuma@volny.cz

绝 +420777620408

\section{INTRODUCTION}

Atherosclerosis is a leading cause of morbidity and mortality in the European Union and elsewhere. Multicentral trials in 44 countries worldwide have confirmed the same clinical characteristics (Bhatt et al. 2006). In 2006 the European Congress of Radiology declared imaging of the vulnerable atherosclerotic plaque to be the main contemporary target in the diagnostics of imminent acute coronary syndromes, stroke, and atherosclerotic 
complications generally. Further comparison of invasive coronary angiography with detection by computed tomography (CT) angiography resulted in the demonstration of about the same number of findings of the reduction of the lumen and their calcifications (Hayes 2006, Savino et al. 2006, Schlosser et al. 2006). Analogous conclusions had to do with magnetic resonance (MR) modality (Yuan et al. 2002, Honda et al. 2007). This paper will pursue an invasive approach to the imaging of the arterial walls and its current position in diagnostics.

\section{VULNERABILITY OF ATHEROSCLEROTIC PLAQUE}

Atherosclerosis is a chronic primary inflammatory intimal vascular disease. It is a result of various interactive mechanisms and influences based on endothelial dysfunction. Subclinical forms of atherosclerosis can exist a long time before clinical manifestation. Changes in the arterial walls have been found in healthy cardiac donors, in young soldiers and even in children and foetuses. Foetal exposure to hypercholesterolemia changes gene expression and arterial wall metabolism. Endothelial dysfunction or the decreased production of nitride oxide or its destruction, for example by increased oxidative stress, are some of the signs of preclinical atherosclerosis (Tuzcu et al. 2001, Tsimikas and Witztum 2002, Kocík et al. 2006).

Atherosclerosis is clinically manifested by its complications due to coronary atherosclerotic plaque disruption with superimposed thrombosis. The rupture causes nearly all heart attacks and many strokes, but the rupture itself does not lead to the symptoms. Plaque characteristics include the proportion of the necrotic to the lipid core, the presence of haemorrhage, the extent of fibrosis, ulceration, calcification, inflammatory cell infiltrate, and fibrous cap thickness. Also the impact of the collateral flow is of great clinical importance. It is not clear why some plaque ruptures lead to acute consequences and others do not. Independent predictors of culprit plaque ruptures leading to symptoms were both the small minimum lumen and the presence of thrombus formation. Vulnerable atherosclerotic plaques with a tendency to rupture are characterized by a thin fibrous cap (65 to $150 \mu \mathrm{m}$ ) and a large lipid core (Fayad and Fuster 2001). In contrast, with a large lipid pool under a thin fibrous cap the calcification itself does not seem to decrease the mechanical stability of the coronary atheroma (Link et al. 1996, Fayad and Fuster 2001, Fujii et al. 2003). Tlymphocytes may be central to plaque instability by stimulating macrophages and inducing apoptosis of smooth muscle cells. An accumulation of T cells and macrophages in the fibrous cap has been correlated for example with plaque ulceration, lumen thrombosis and even with transcranial Doppler emboli frequency and cortical symptoms (Oliver et al. 1999, Golledge et al. 2000, Huang et al. 2001).

Major determinants of the vulnerability of the plaque to rupture are the size and consistency of the atheromatous core, and ongoing inflammation within the cap. Plaque disruption tends to occur at points at which the plaque surface is weakest and most vulnerable. There are points where stresses resulting from the biomechanical and haemodynamic forces influencing plaque are concentrated. Thrombosis occurs because denudation and erosion of the endothelial surface cause the exposure of blood to highly thrombogenic plaque components and consequent disruption of lipid-rich plaques. (Golledge et al. 2000) (Fig.1).

\section{SUBCELLULAR STUDIES}

The results of comparative studies can be more or less accepted. Further understanding has to lead to better detection of unstable plaques and to consequent developments in therapeutic methods of plaque stabilization. Therefore, the crucial question is why atherosclerosis suddenly becomes complicated by life-threatening thrombosis. Research has concentrated on the subcellular molecular level, atherosclerotic proteins with an affinity to endothelial cells, the fibrin-targeted agent enhancing detection of mictrothrombi of vulnerable plaques, the role of the insulin-like growth factor-1 (IGF-1) and other applied modalities in detecting the pathogenesis of atherosclerosis (Colao et al. 2004, Colao et al. 2005). Vulnerable atherosclerotic plaques characterized by high numbers of inflammatory cells, macrophages, and proteins can be identified thanks to levels of inflammation within atheromatous lesions quantified by positron emission tomography (PET) and single-photon emission computed tomography (SPECT) imaging. 


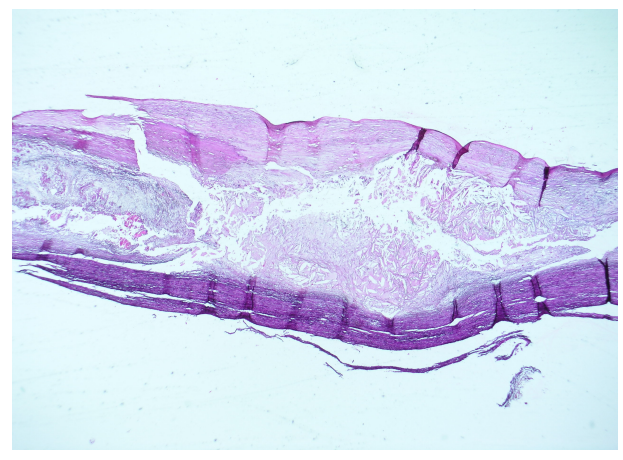

A

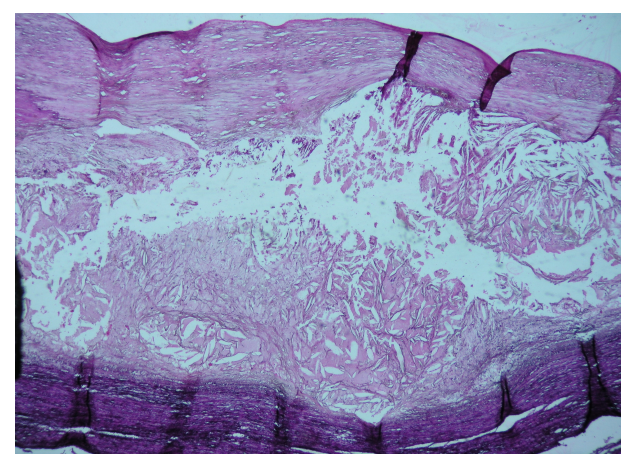

$B$

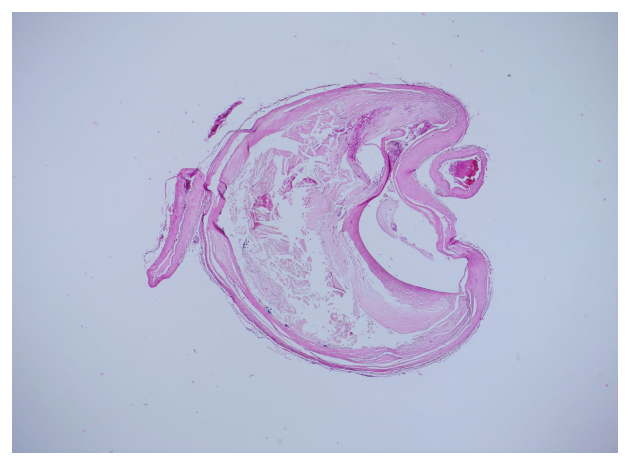

C

Fig. 1. Atherosclerotic plaque - morphological consistency (Courtesy of the Department of Pathological Anatomy, $2^{\text {nd }}$ Medical Faculty, Charles University, Prague, CZ). (A) Transsectional histological view on the stenotic lumen of the vertebral artery due to the atherosclerotic plaque. (B) Rupture of the thin fibrotic cap with a large lipid core and underlying calcification. The destroyed elastic membranes in the media are seen. (C) Transsection of the artery with persistent minimal lumen. Robust necrotic and hemorrhagic lipid core. In adventitia the proliferation of the vasa vasorum is seen. (Courtesy of Institute of Pathology, $2^{\text {nd }}$ Medical Faculty, Charles University, Prague, CZ).
Tracer compounds - glucose derivates FDG - have been developed and tested in the vessels (Ross et al. 1999). Tracer compounds capable of assessing macrophage recruitment, foam cell generation, matrix metalloproteinase production, macrophage apoptosis, and macrophage metabolism have been developed and tested in the carotid and peripheral circulation (Davies et al. 2006). The development of a method which depends on the technical improvement of scanners is promising.

Experimental studies on mice have not proved an increased FDG uptake by the vulnerable, inflamed atherosclerotic lesions and therefore it has not been possible to detect lesions by the FDG-PET (Okane et al. 2006). Recently, however, positron emission tomography (PET) together with computed tomography - PET/CT - was presented as a hit in the demonstration by F 18 Fluorodeoxyglucose (FDG) PET imaging of inflammation of the arterial wall, in, for example patients with Takayasu's and temporal arteritis. The hybrid $\mathrm{PET} / \mathrm{CT}$ angiography remains in the same position, giving information about the general progress of the atherosclerotic process, but no detailed information concerning tissue quality and plaque composition (Haberl 2001, Haberl and Steinbigler 2001, Warburton and Gillard 2006) (Fig.2).

\section{ULTRASOUND IN ARTERIAL WALL IMAGING}

It seems that a combined approach using ultrasound (US) and FDG-PET might also be helpful in the diagnosis of atherosclerosis (Pfadenhauer and Rull 2005). In the emergency clinical approach to the patient with atherosclerotic complications, ultrasound is assumed to be primary in imaging techniques. Risk factors have been consistently related to an increase in carotid intima-media thickness (IMT). In selected populations and even in the low-risk population, an increased IMT might reflect local atherosclerosis (Ferrieres et al. 1999). Attention was paid to intima-media thickness but the presence of plaque appeared to be the major criterion of a high risk of disease. Further work is required to understand the significance of the thicker IMT in the absence of plaque (Ebrahim et al. 1999). Carotid intima-media thickness (IMT) and aortic calcifications are related most strongly to the risk of future coronary heart disease and stroke (Hollanderv et al. 2003). Whether testing for them will become components of routine clinical care 


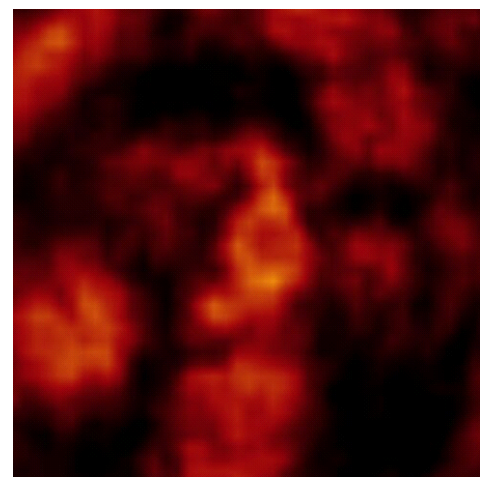

$A$

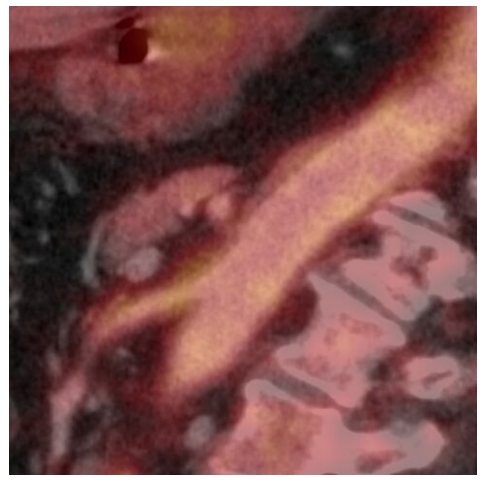

C

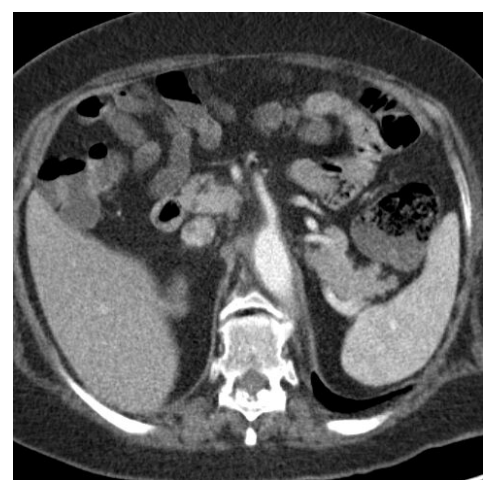

$B$

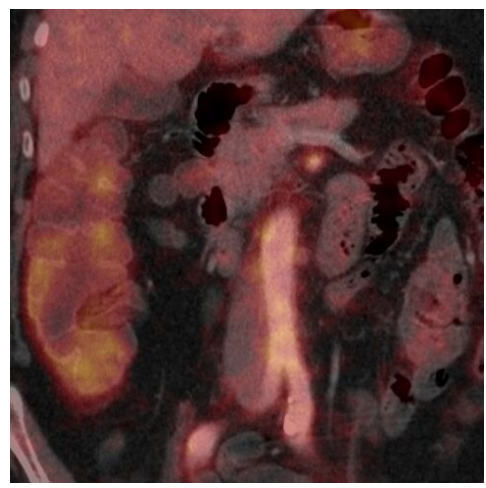

$D$

Fig. 2. Calcified atherosclerotic plaque at the aortical wall - PET/CT (Courtesy of the PET Center, Hospital Na Homolce, $1^{\text {st }}$ Medical Faculty, Charles University, Prague, CZ). (A) Transversal CT section of the aortic arch with the calcified atherosclerotic plaque. (B) PET/CT at the same level with the uptake of the 18-Fluorodeoxyglucose demonstrates persistent metabolic activity of the atherosclerotic process in the aortic wall near the calcified part. (C) and (D) The same process seen in reconstruction at the coronal view.

depends on whether the results of such testing will have direct therapeutic consequences. It has been demonstrated that diagnostic information about atherosclerotic changes in one carotid artery can be applied to the contralateral one (Adams et al. 2002). The use of mean maximum IMT may be recommended as the primary outcome measure (Bots et al. 2003). The measurement of near wall carotid IMT also appears to yield valuable information (Fiedler et al. 2006). The practical angle of those studies is that an IMT value of the common carotid artery of under $0.835 \mathrm{~mm}$ in patients without stenocardia and without known ischemic heart disease allows a very high degree of specificity and so can avert coronarography before heart valvular surgery (Rosvall et al. 2003) (Fig.3). On the other hand there were no differences in strokes in the presence or absence of plaques in the carotid artery walls (Kovárník et al. 2006). As risk plaques with a rupture are significantly greater and more frequent with a large necrotic core (Brunenberg et al. 2006), the intravascular ultrasound (IVUS) with its capacity to extract texture features has been used in an attempt to develop an automatic tissue characterization method (Halliburton et al. 2006). Intravascular ultrasonography (IVUS) also allows us to differentiate tissues with the direct use of varying frequencies and to demonstrate their relationship by the way of virtual histology. The use of IVUS 
continues to evolve during percutaneous coronary interventions. Emerging IVUS-based technologies such as three-dimensional reconstruction, automated quantitative three-dimensional (3-D) IVUS methods, elastography or spectral analysis and imaging guide wires have increased their use and feasibility in the identification of vulnerable plaques (Von Birgelen et al. 1997, Červinka et al. 2000, Von Birgelen and Hartmann 2004, Sipahi et al. 2006, Valgimigli et al. 2006). As the elevated circulating C-reactive protein (CRP) has commonly been observed in patients with acute coronary syndrome, suggesting increased inflammation in vulnerable plaques (Sawada et al. 2006), study using the IVUS has continued. Spectral analyses of IVUS radiofrequency data (IVUS-Virtual Histology) revealed that an elevated level of high sensitive CRP plasma was correlated with a necrotic core volume in patients with acute coronary syndrome, both in culprit and non-culprit

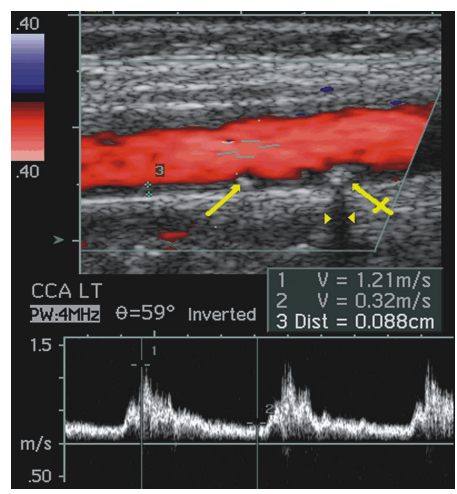

A

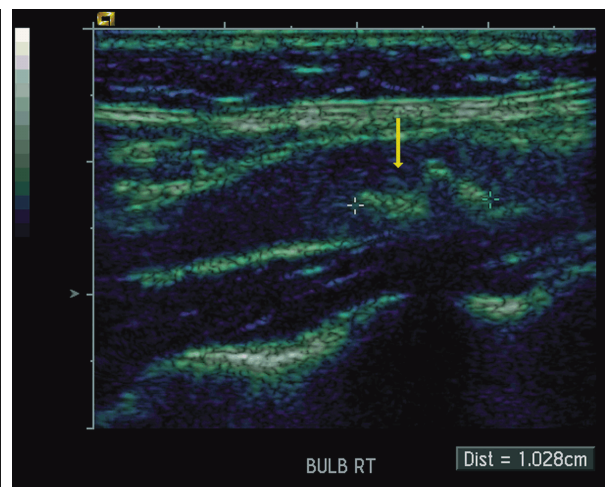

$B$

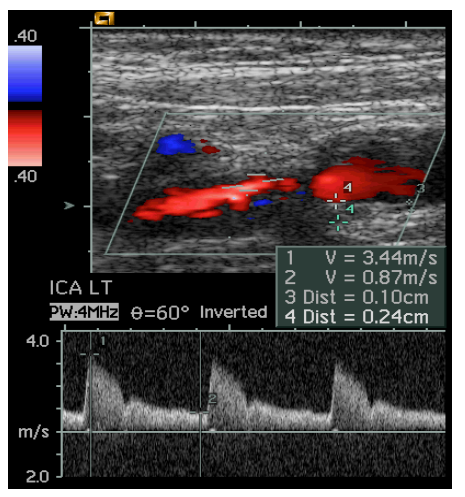

C

Fig. 3. Colour coded US and spectral curves of the carotid arteries. (A) Two small atherosclerotic plaques with calcification and distal acoustic shadow (arrow). Mild increased flow due to narrowing to $30 \%$. The intima-media thickness (IMT) ratio is $0.9 \mathrm{~mm}$. (B) The bulb of the carotid artery with $10 \mathrm{~mm}$ long atherosclerotic plaque and exulceration (arrow). (C) Stenotic flow due to the robust in homogeneous exulcerated atherosclerotic plaque with acoustic shadow.

lesions, suggesting an increased vascular inflammation (Blaško et al. 2006, Sawada et al. 2006, Takayama et al. 2007). On the other hand it did not confirm previously found differences in the incidence of thin-cap fibroatheroma, thick fibroatheroma or the presence of multiple necrotic core layers between patients with stable angina and those with acute coronary syndrome (RodriguezGranillo et al. 2005, 2006, Nasu et al. 2006, Surmely et al. 2006, Valgimigli et al. 2007 ) (Fig.4).

\section{DUAL ENERGY MULTIDETECTOR COMPUTED TOMOGRAPHY AND MAGNETIC RESONANCE IMAGING}

The effect of intra-arterial injection of an iodinated contrast agent on the attenuation of individual plaque components led to the contrast enhancement of noncalcified plaques including both fibrous and fibrofatty plaques (Halliburton et al. 2006). It is possible to accept that atherosclerotic plaque components can be characterized with a multidetector-row CT based on differences in Hounsfield unit (HU) values. Recent results allow us to quantify the total plaque area, calcifications, and fibrous tissue by means of dual-energy (DE) (or dual-source - DS) multidetector computed tomography (MDCT) in good correlation with the histology, perhaps with the exception only of lipid core areas (Fig.5). CTA axial images correlated with digital subtraction angiography (DSA) more closely than US with DSA and were superior to US (Anderson et al. 2000, Porsche et al. 2001, De Weert et al. 2006, Rieber et al. 2006). Good correlation was found in the detection of ulcers associated with carotid stenosis. Also the US was found to be relatively inaccurate in the quantification of carotid stenosis. Vascular wall and fibromuscular plaque achieved a significant 
increase in contrast-to-noise ratios (CNR) when DE MDCT imaging techniques were used. MR nanoparticles of contrast with the integrin $\alpha_{\mathrm{V}} \beta_{3}$ can also be used as angiogenic markers of atherosclerosis at the early identification of vulnerable and inflamed plaque. Using intravascular ultrasound, the reversal of the build up of plaque in the coronary arteries due to intensive lowering of cholesterol with a statin drug was observed. Furthermore, in several studies clear

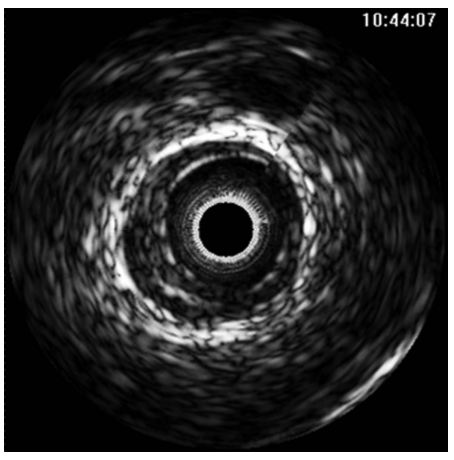

A

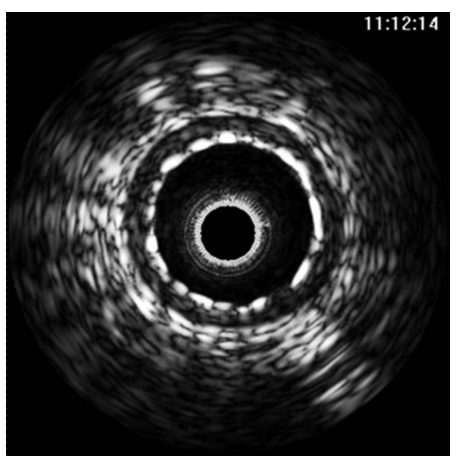

C visualization of the anatomy and even histology and documentation of plaque morphology in patients with advanced atherosclerosis was achieved in samples both in vitro and in vivo by the MRA with several modifications (Coombs et al. 2001, Alvarez-Linera et al. 2003, Saam et al. 2006, Sailer et al. 2006, Warburton and Gillard 2006). MR imaging can demonstrate high signals, which correspond to the histologically confirmed partial

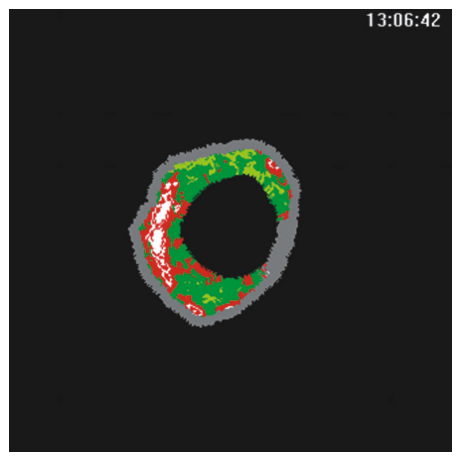

$B$

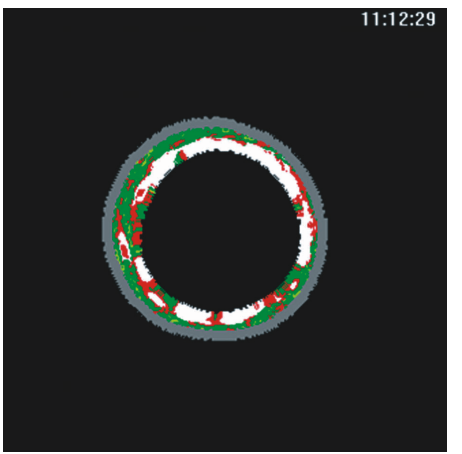

$D$

Fig. 4. IVUS $(A, C)$ and virtual histology $(B, D)$ before interventional angioplasty $(A, B)$ with stenting and after that $(C, D)$. IVUS characteristics in virtual histology imaging of the coronary artery wall tissues: White - calcification in the wall, pale green - fatty fibrous tissue, dark green - fibrosis, red - necrotic changes of the plaque.

lipid core or haemorrhagic components in the fibrous tissues. So magnetic resonance imaging could be useful in characterizing factors associated with plaque instability, and may help guide therapeutic strategies (Honda et al. 2007).

\section{DIGITAL SUBTRACTION ANGIOGRAPHY AND THE ROLE OF INVASIVE METHODS}

Generally we accept the thesis that DSA is still a gold standard method, particularly in urgent 
situations. Nevertheless, we have to state that even better correlations have been published in several other modalities, for example in the Anderson's study (Anderson et al. 2000). Regardless of useful pre-invasive information gained by non-invasive investigations, the $\mathrm{CT}$ angiography and $\mathrm{MR}$ angiography remain confirmed possibilities in non classical and delayed situations.
Progress in imaging of the arteries continues from luminal angiography to the quantitative evaluation of the extent and quality of atherosclerotic disease. Now the new practice of preventive cardiology uses the concept of the "vulnerable patient." The Screening for Heart Attack Prevention and Education (SHAPE) Task Force presents new guidelines for the non-invasive

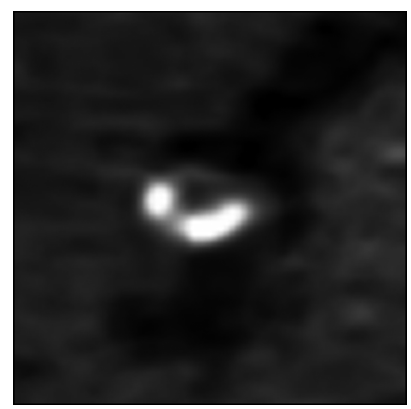

$A$

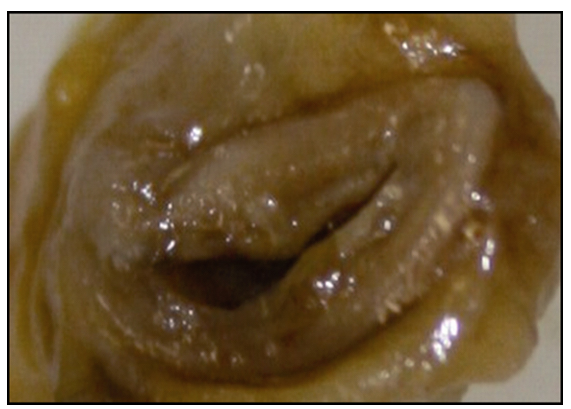

$B$

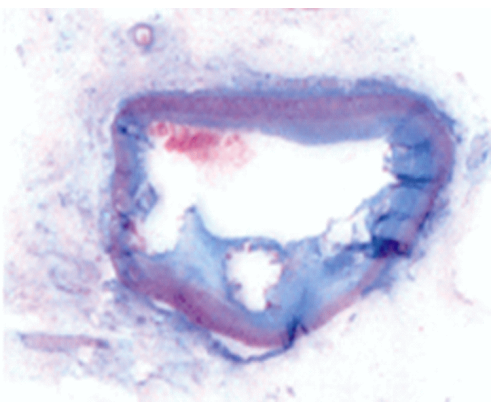

C

Fig. 5. Dual energy (dual source) $\mathrm{CT}$ of the noncalcified atherosclerotic plaque of the coronary artery with histological correlation. (A) Dual source CT slice $0.75 \mathrm{~mm}$ thickness of the coronary artery wall with the noncalcified atherosclerotic changes. Unstable plaque characterized by intraplaque hemorrhage and subsequent iron deposits change CT values of different elements in different way. (B) Post mortem macroscopic view on the thrombotic arterial lumen with the plaque hemorrhage. (C) Histological findings - correlation of the same place.

cardiovascular screening of the asymptomatic atrisk population for the detection and treatment of those with subclinical atherosclerosis (Bhatt et al. 2006). All methods are informative in one way or another with regard to the role of plaque remodeling and composition in disease causation (Crouse 2006, Naghavi et al. 2006). Recent results of clinical trials (Ross's, CAPTIM, Prague, CZ) recommend facilitated intervention - primary angioplasty together with prehospital fibrinolysis - as the urgent therapeutical method of choice (Ross et al. 1999, Herrmann 2000, Bonnefoy et al. 2002, Nalamothu and Bates 2003, Widimsky et al. 2003). Urgent diagnostics to be followed by immediate therapy remain focused on fluorography. The invasivity of the life-saving emergency is based on two principle methods: angiography and intravascular ultrasonography. Association of these methods with ionizing radiation is, together with other iatrogenic influences, to be added to burden of cardiovascular risk factors. The main disadvantages of selective coronary angiography are: there is no imaging of the initial phases of the atherosclerotic transmodelling of the arterial walls before the luminal narrowing, there is low sensitivity in the detection of thrombotic formation, imaging of the vascular ulceration is unsatisfactory and dissection because of angioplasty. Investigations lead from angiography and digital subtraction angiography to three-dimensional imaging, together with the rotational acquisition of angiographic pictures. Although the topographic findings associated with atherosclerotic changes are increasingly better understood by means of various digital non-invasive techniques, introducing three-dimensional invasive imaging should ease the innovation of interventional procedures (Missler et al. 1994).

The Prague - Motol trial supported by the Ministry of Health (IGA MZ ČR No. NR/7941 - 3) introduced three-dimensional invasive imaging by means of the rotational angiography (3D-RA) in the diagnostics of atheromatous plaques at the carotid artery bifurcation. The complexity of the information received and the low level of ionizing radiation were surprising.

The size of the calcified atheromatous plaques measured by the 3D-RA Philips Allura system with the Calci-View programme allowed the calculation 

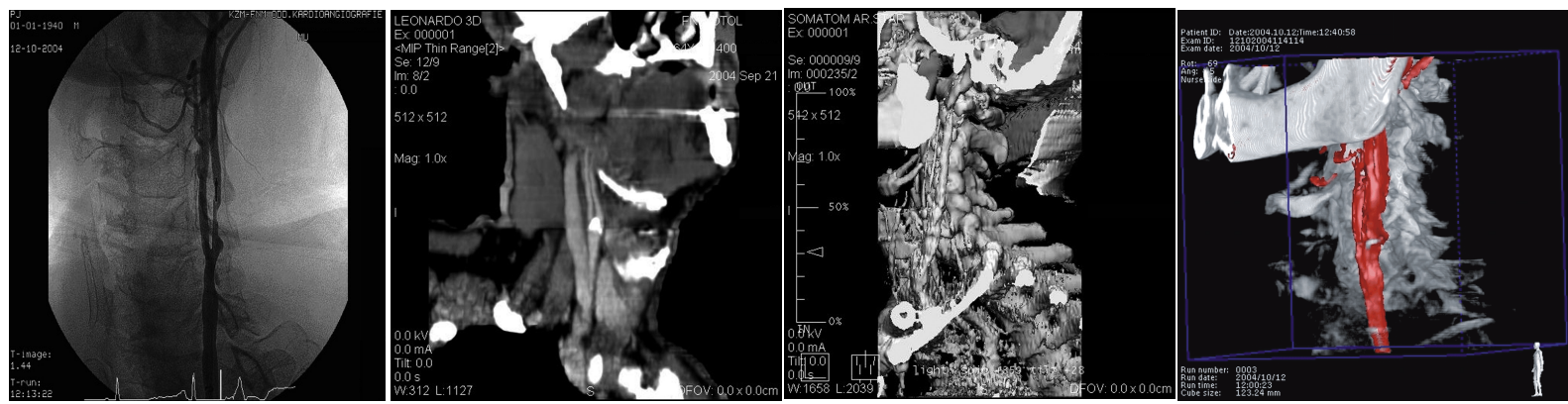

$A$

$B$

$C$

$D$

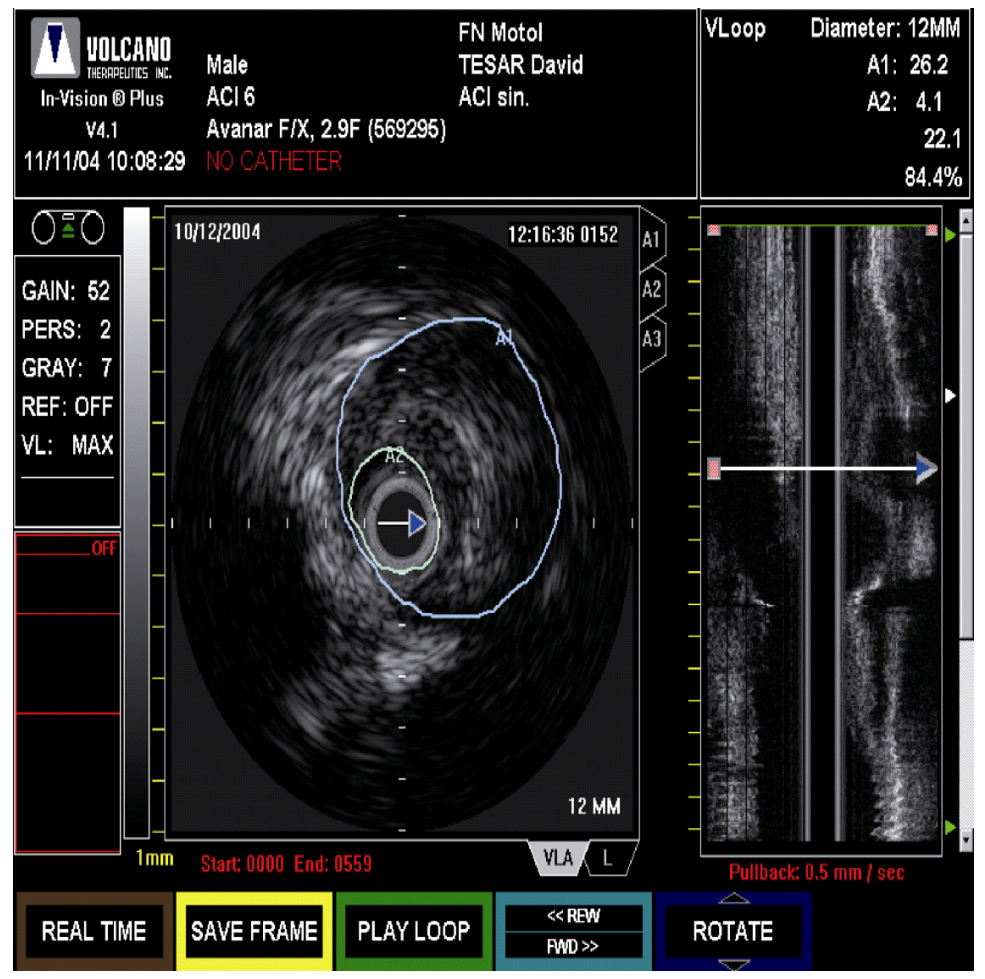

$E$

Fig. 6. Three-dimensional rotational angiography (3D RA) approach to the interventional procedure in patient with atherosclerotic carotid artery stenosis. (A) Selective DSA of the left carotid artery. Stenosis of the internal carotid artery due to the atherosclerotic plaque. (B) CT angiography with maximum intensity projection at the left anterior oblique view. Calcified atherosclerotic plaque. (C) D CTA of the same place in volume rendered technique. (D) Three-dimensional rotational angiography (Philips Integris-Allura) with multi-threshold shaded surface display and colour coded demostration of the calcified plaque at the stenotic wall of the left carotid artery. (E) IVUS characteristics of the stenotic carotid artery and measurement of the tissue quality of the arterial wall.

of the percentage of stenosis by the quantified carotid arteriography (QCA). In absolute numbers the measured calcification had a lesser volume, and the stenotic area was overestimated compared with that obtained with the use of the IVUS. The 3D-RA was superior to the DSA, CT and IVUS and accurately depicted the site and morphology of stenotic plaques in the carotid arteries bifurcation. 
Tưma et al.: Plaque imaging: clinical implications and use of invasive methods
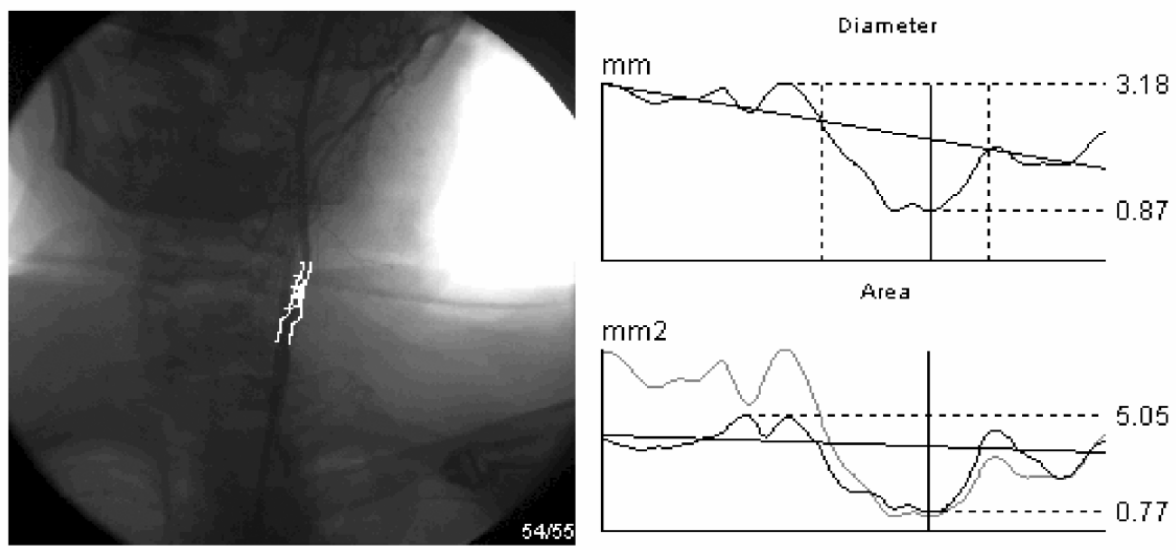

Computer Defined Obstruction Analysis

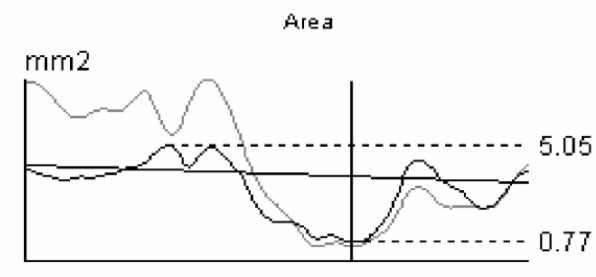
MLA Geom.
MLA Geom.
Pos. Prox. Border
Ref. Diam
Ref. Area

$0.87 \mathrm{~mm}$

$0.60 \quad \mathrm{~mm} 2$

Obstr. Length : $7.41 \mathrm{~mm}$

$9.93 \mathrm{~mm}$

$2.16 \quad \mathrm{~mm}$

Type : Catheter

Calibration size : $7.00 \quad$ French 0.00 French

Pixel size : $0.27 \quad \mathrm{~mm} \quad 0.01 \mathrm{~mm}$

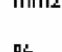

Sealing Factor : : 0.08

Magn. Factor : 1.0

Background Cor. : yes

\%[D-Sten.

phisten. Geom.

魚-Sten. Dens.

60

吅
吅

Physician : MUDr.Tesar Dawid

Exam. Date : 2/1/2005

Obstr. Wolume

Plaque Area

Plaque vilum

79

吅

$12.21 \mathrm{~mm} 3$

$5.31 \mathrm{~mm} 2$

$14.00 \mathrm{~mm} 3$

Patient Name : PJ

Patient Id : Date:2004.10.12;Time:12:44:33

Birth Date : $1 / 1 / 1940$

Symmetry

0.02

Fig. 7. Evaluation of the carotid artery stenosis with diameter and volume obstruction characteristics analysed by the measurement using the quantified angiographic features.

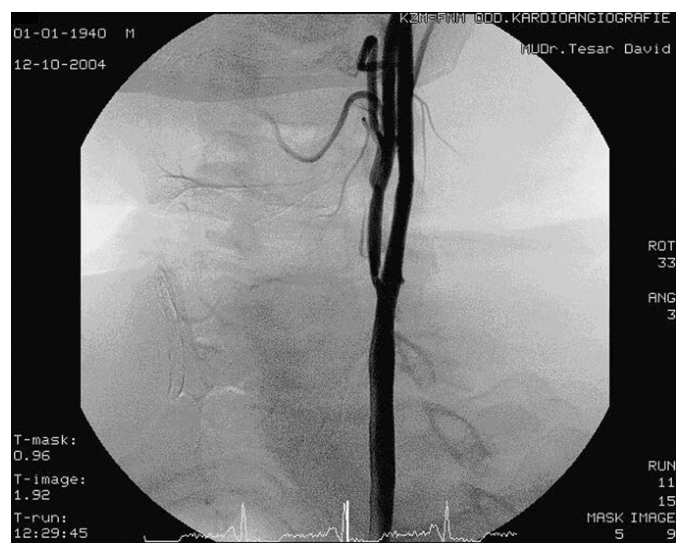

Fig. 8. DSA of the left carotid artery after an interventional procedure with angioplasty and stenting. 
The new "gold standard" modality for diagnosis of non-calcified plaques now seems to be the interventional ultrasound (IVUS). The crosssectional view of IVUS demonstrates the size of the atherosclerotic plaque, its distribution in the vessel wall and its tissues and includes information about the composition of unstable vulnerable plaque and even the therapeutical effect of statins with the decreased or interrupted growth of plaques. The development of fast imaging in 3D RA offers a new approach to the assessment of quality of the arterial atheromatic plaque with sufficient tissue contrast, and improves the making of a decision in favour or against immediate angioplasty. (Figs. 6, 7, 8).

Rotational angiography often depicts more severe ICA stenosis in comparison with conventional DSA in two or three projections. This indicates a limitation in conventional DSA as the reference-standard method for establishing the maximum artery stenosis (Elgersma et al. 1999). Although the topographic changes associated with atherosclerotic changes are increasingly better understood, a correct radiological diagnosis may be difficult. Stenosis of the carotid artery bifurcation is frequently found especially in older patients with atherosclerosis.

According to the interventional procedure the ideal device for the protection of the brain does not yet exist. The response of the arterial wall to therapy should also be demonstrated. The combination of the 3D-RA and DSA with IVUS visualizes the spacial extent of the stenosis and indicates the tissue quality of the plaque very well. Compared to DSA, MRA, IVUS, and spiral CTA using the clinical evaluation and the interventional results as reference, 3D-RA seems to be acceptable and advantageous. Experimentally there are several new invasive technologies being studied to detect atherosclerotic plaques: thermography, optical coherence tomography, Raman spectroscopy, and NearInfrared (NIR) spectroscopy, until now without any direct practical impact (Fayad and Fuster 2001).

The role of invasive methods is in distinguishing focal or generalized pathological processes. They can be used in the demonstration of the location and size of the atherosclerotic plaque and in attracting attention to the danger of its vulnerability that is the recognition of the plaque tissues, namely the lipid core, not only the calcified parts of the plaque. However, the response of the arterial wall to therapy - both immediately after the angioplasty and stenting and later, after continuing pharmaceutical therapy by statins - is yet to be demonstrated. Moreover the invasive approach prepares the way for up-to-date application of the cell therapy in cardiology (Fayad and Fuster 2001). For the future it seems to be leading the multidisciplinary approach together with endovascular therapy of peripheral vascular disease. There is now a unique oportunity to interact with other disciplines working in this field. We are willing to spread the multidisciplinary view amongst vascular healthcare professionals, of how the endovascular future might look.

\section{CONCLUSIONS}

Clinical complications of atherosclerosis are due to the rupture of the atherosclerotic plaque with overlying thrombosis. The value of invasive methods for the detection of atherosclerotic plaques is not only in distinguishing the pathological process or location and size of the plaque and its calcified parts but also in attracting attention to the danger of its vulnerability. The plaques inclining to rupture (unstable vulnerable plaques) contain a large lipid core covered by a thin fibroplastic cap layer with an amount of macrophages and mastocytes. They seem to be demonstrable by new "gold-standard" modality as described. Intravascular ultrasonography allows us to differentiate tissues directly using varying frequencies and to demonstrate their relationship by means of virtual histology. X-ray densitometry promises such differentiation in future by means of dual-energy multidetector computed tomography. Angiography of the atherosclerotic plaque tissues leads from digital subtraction to the threedimensional imaging, for example together with the rotational acquisition of angiographic pictures.

\section{ACKNOWLEDGMENT}

Authors want to send personal thanks to colleagues from the Department of Pathology and Molecular Medicine, $2^{\text {nd }}$ Medical Faculty, Charles University, Prague, Clinic of Radiodiagnostics, Medical Faculty, Charles University, Plzeň, and PET Centre, Na Homolce Hospital, Prague, Czech Republic, for their kind help in completion of the image documentation. Their efforts are very much appreciated. 


\section{REFERENCES}

Adams GJ, Simoni DM, Bordelon CB Jr., Vick GW III, Kimball KT, Insull WI Jr., Morrisett JD: Bilateral symmetry of human carotid artery atherosclerosis. Stroke 33: 2575-2580, 2002.

Alvarez-Linera J, Benito-León J, Escribano J, Campollo J, Gesto R: Prospective evaluation of carotid artery stenosis: elliptic centric contrast-enhanced MR angiography and spiral CT angiography compared with digital subtraction angiography. Am. J. Neuroradiol. 24:1012-1019, 2003.

Anderson GB, Ashfort R, Steine DE, Fernandy R, Findlay JM: CT angiography for the detection and characterization of carotid artery bifurcation disease. Stroke 312:2168-2174, 2000.

Bhatt DL, Steg PG, Magnus Ohman EM, Hirsch AT, Ikeda, Y, Mas, J-L, Goto S, Liau C-S, Richard AJ, Röther J, Wilson PWF: International prevalence, recognition, and treatment of cardiovascular risk factors in outpatients with atherothrombosis. JAMA 295:180-189, 2006.

Blaško P, Ošt'ádal P, Malý M, Veselka J: IVUS virtual histology in the interventional cardiology. Cor Vasa 48:217, 2006.

Bonnefoy E, Lapostolle F, Leizorovicz A, Steg G, McFadden EP, Dubien PY, Cattan S, Boullenger E, Machecourt J, Lacroute JM, Cassagnes J, Dissait F, Touboul P: Primary angioplasty versus prehospital fibrinolysis in acute myocardial infarction. Lancet 360:890-892, 2002.

Bots ML, Švand GW, Riley WA, Grobbee DE: Carotid intima-media thisckness measurements in intervention studies. Design options, progression rates, and sample size consideration: a point of view. Stroke 34:2985-2994, 2003.

Brunenberg E, Pujol O, Ter Haar Romeny B, Radova P: Automatic IVUS segmentation of atherosclerotic plaque with stop \& go snake. Lect. Notes Comput. Sci. (Lect. Notes Artif. Intelligence Bioinformatics) 4191 LNCSII:9-16, 2006.

Červinka P, De Feyter PJ, Costa M, Sabaté M, Ligthart JMR, Št'ásek J: Intravascular ultrasound in cardiology. Vnitř. Lék. 46:470-475, 2000.

Colao A, Di Somma C, Filippella M, Rota F, Pivonello R, Orio F, Vitale G, Lombardi G.:
Insulin-like growth factor-1 defficiency determines increased intima-media thickness ata common carotid arteries in adult patiens with growth hormone deficienty. Clin. Endocrinol. (Oxf) 61:360-366, 2004.

Colao A, Spiezia S, Di Somma C, Pivonello R, Marzullo P, Rota F, Musella T, Auriemma RS, De Martino MC, Lombardi G: Circulating insulin-growth factor-1 levels are correlated with the atherosclerotic profile in healthy subjects independenty of age. J. Endocrinol. Invest. 28:440-448, 2005.

Coombs BD, Rapp JH, Ursell PC, Reilly LM, Saloner D: Structure of plaque at carotid bifurcation. High resolution MRI with histological correlation. Stroke 32:2516-2521, 2001.

Crouse JR: Thematic review series: patient-orinted research. Imaging atherosclerosis: state-of-theart. J. Lipid Res. 47:1677-1699, 2006.

Davies JR, Rudd JH, Weissberg PL, Narula J: Radionuclide imaging for the detection of inflammation in vulnerable plaques. J. Am. Coll. Cardiol. 18 (Suppl. 8):C57-68, 2006.

De Weert TT, Ouhlous M, Meijering E, Zondervan PE, Hendriks JM, van Sambeek MRHM, Dippel DWJ, van der Lugt A: In vivo characterization and quantification of atherosclerotic carotid plaque components with mulltidetector computed tomography and histopathological correlation. Arterioscler. Tromb. Vasc. Biol. 26:2366-2372, 2006.

Ebrahim S, Papacosta O, Whincup P, Wannamethee G, Walker M, Nicolaides AN, Dhanjil S, Griffin M, Belcaro G, Rumley A, Lowe GDO: Carotid plaque, intima thickness, cardiovascular risk factors, and prevalent cardiovascular disease in men and women: the British Regional Heart Study. Stroke 30:841-850, 1999.

Elgersma OEH, Buijs PC, Wüst AFJ, van der Graaf Y, Eikelboom BC, Mali WPTM: Maximum internal carotid arterial stenosis: assessment with rotational angiography versus conventional intraarterial digital subtraction angiography. Radiology 213:777-783, 1999. Fayad ZA, Fuster V: Clinical imaging of the high-risk or vulnerable atherosclerotic plaque. Circ. Res. 89:305-316, 2001.

Ferrieres J, Elias A, Ruidavets JB, Cantet C, Bongard V, Fauvel J, Boccalon H: Carotid intima-media thickness and coronary heart disease risk factors in a low-risk population. J. Hypertens. 17:743-748, 1999. 
Fiedler J, Pavlů L, Molínský J: Predikuje nezvětšená hodnota šíre komplexu intimamedia společné karotidy absenci významných stenóz při koronarografii u nemocných indikovaných $\mathrm{k}$ operačnímu řešení chlopenní vady a s absencí stenokardií? XXXII. den mladých kardiologů, Sanofi-Aventis, Praha, Abstr.:44, 2006.

Fujii K, KobayashiY, Mintz GS, Takebayashi H, Dangas G, Moussa I, Mehran R, Lansky AJ, Kreps E, Collins M, Colombo A, Stone, GW, Leon MB, Moses JW: Intravascular ultrasound assessment of ulcerated ruptured plaques. A comparison of culprit and nonculprit lesions of patiens with acute coronary syndromes and lesions in patiens without acute coronary syndromes. Circulation 108:2473-2478, 2003.

Golledge J, Greenhalgh RM, Davies AH: The symptomatic carotid plaque. Stroke 31:774-781, 2000.

Haberl R: New concepts in cardiac imaging. J. Clin. Basic Cardiol. 4:240, 2001.

Haberl R, Steinbigler P: New perspectives of noninvasive imaging with cardiac CT. J. Clin. Basic Cardiol. 4:241-243, 2001.

Halliburton SS, Schoenhagen P, Nair A, Stillman A, Lieber M, Tuzcu EM, Vince DG, White RD: Contrast enhancement of coronary atherosclerotic plaque: A high-resolution, multidetector-row computed tomography study of pressure-perfused, human ex-vivo coronary arteries. Coron. Artery Dis. 17:553-560, 2006.

Hayes E: Researchers confront strengths, limitations of 64-slice CTA. Diagn. Imaging Europ. 22:5-6, 2006.

Hermann HC: Triple therapy for acute myocardial infarction: combining fibrinolysis, platelet IibIIIa inhibition and percutaneous coronary intervention. Am. J. Cardiol. 85 (Suppl. C):10-16, 2000.

Hollander M, Hak AE, Koudstaal PJ, Bots ML, Grobbee DE, Hofman A, Witteman JCM, Breteler MMB: Comparison between measures of atherosclerosis and risk of stroke. The Rotterdam Study. Stroke 34:2367-2373, 2003.

Honda M, Kawahara I, Kitagawa N, Tsutsumi K, Morikawa M, Hayashi $T$, Nagata I: Asymptomatic carotid artery plaques: use of magnetic resonance imaging to characterize vulnerable plaques in 65 cases. Surg. Neurol. 67:35-39, 2007.

Huang H, Virmani R, Younis H, Burke AP, Kamm
RD, Lee RT: The impact of calcification on the biomechanical stability of atherosclerotic plaques. Circulation 103:1051-1056, 2001.

Kocík M, Málek I, Janek B, Želízko M, Pirk J: Výskyt aterosklerotického postižení věnčitých tepen $\mathrm{v}$ populaci dárců srdce. Cor Vasa 45: 299-303, 2006.

Kovárník T, Horák J, Dostál O, Aschermann M: Rozdíly v morfologii aterosklerotických plátů ve věnčitých tepnách u nemocných se stabilní a nestabilní anginou pectoris. Studie s intravaskulárním ultrazvukem a virtuální histologií. XXXII. den mladých kardiologů, Sanofi-Aventis, Praha, Abstr. 29, 2006.

Link J, Grossmann J, Grabener M, Mueller Huelsbeck S, Steffens JC, Brinkmann G, Heller M: Spiral CT angiography and selective digital subtraction angiography of internal karotid artery stenosis. Am. J. Neuroradiol. 17:89-94, 1996.

Missler U, Mayer T, Brückmann H, Kamm KF: Erste Erfahrungen mit der Rotationsangiographie in der Neuroradiologie. Kontraste 6:2-7, 1994.

Naghavi M, Falk E, Hecht HS, Jamieson MJ, Kaul S, Berman D, Fayad Z, Budoff M, Rumberger J, Shah PK: From vulnerable plaque to vulnerable patient-Part III: Executive summary of the Screening for Heart Attack Prevention and Education (SHAPE) Task Force report. Am. J. Cardiol. 98 (2 Suppl 1):2-15, 2006.

Nalamothu BK, Bates ER: Percutaneous coronary intervention versus fibrinolytic therapy: is timing (almost) everything? Am. J. Cardiol. 92:924-826, 2003.

Nasu K, Tsuchikane E, Katoh O, Vince D, Virmani R, Surmely J, Murata A, Takeda Y, Ito T, Ehara $\mathrm{M}$ : Accuracy in vivo coronary plaque morphology assessment: a validation study of in vivo virtual histology compared with in vitro histopathology. J. Am. Coll. Cardiol. 47:2405-2412, 2006.

Okane K, Ibaraki M, Toyoshima H, Sugawara S, Takahashi K, Miura S, Shimosegawa E, Satomi J, Kitamura K, Satoh T: ${ }^{18} \mathrm{~F}-\mathrm{FDG}$ accumulation in atherosclerosis: use of $\mathrm{CT}$ and MR co-registration of thoracic and carotid arteries. Eur. J. Nucl. Med. Mol. Imaging 33:589-594, 2006.

Oliver TB, Lammie A, Wright AR, Wardlaw J, Patel SG, Peek R, Ruckley V, Collie DA: Atherosclerotic plaque at the carotid bifurcation: CT angiographic appearance with 
histopathologic correlation. Am. J. Neuroradiol. 20:897-901, 1999.

Pfadenhauer K, Rull T: Ultrasonographic and FDGPET imaging in active giant cell arthritis of the carotid arteries. Vasa 34:269-271, 2005.

Porsche C, Walker L, Mendelow D, Birchall D: Evaluation of cross-sectional luminal morphology in carotid atherosclerotic disease by use of spiral CT angiography. Stroke 32:2511-2515. 2001.

Puppini G, Furlan F, Cirota N, Veraldi G, Piubello Q, Montemezzi S, Gortenuti G: Caratterizzazione delle placche carotidee aterosclerotiche: Comparazione tra risonanza magnetica e istologia. Radiol. Med. (Torino) 111:921-930, 2006

Rieber J, Meissner O, Babaryka G, Reim S, Oswald M, Koenig A, Schiele TM, Shapiro M, Theisen K, Reiser MF, Klauss V, Hoffmann U: Diagnostic accuracy of optical coherence tomography and intravascular ultrasound for the detection and characterization of atherosclerotic plaque composition in ex-vivo coronary specimens: A comparison with histology. Coron. Artery Dis. 17:425-430, 2006.

Rodriguez-Granillo GA, Mc Fadden EP, Valgimigli M, van Mieghem CA, Regar E, de Feyter PJ, Serruys PW: Coronary plaque composition of non-culprit lesions, assessed by in vivo intracoronary ultrasound radiofrequency data analysis, is related to clinical presentation. Am. Heart J. 151:1020-1024, 2006.

Rodriguez-Granillo GA, Garcia-Garcia HM, Mc Fadden EP, Valgimigli M, Aoki J, De Feyter $\mathrm{P}$, Serruys $\mathrm{PW}$ : In vivo intravascular ultrasound-derived thin-cap fibroatheroma detection using ultrasound radiofrequency data analysis. J. Am. Coll. Cardiol. 46:2038-2042, 2005.

Ross AM, Coyne KS, Reiner JS, Greenhouse SW, Fink C, Frey A, Moreyra E, Traboulsi M, Racine N, Riba AL, Thompson MA, Rohrbeck $\mathrm{S}$, Lundergan $\mathrm{CF}$ : A randomized trial comparing primary angioplasty with a strategy of short-acting thrombolysis and immediate planned rescue angioplasty in acute myocardial infarction: the PACT trial. J. Am. Coll. Cardiol. 34:1954-1962, 1999.

Rosvall M, Janzon L, Berglund G, Engström G, Hedblad B: Incidence of stroke is related to carotid IMT even in the absence of plaque. Atherosclerosis 179:325-331, 2005.

Saam T, Cai J, Ma L, Cai Y-Q, Ferguson MS,
Polissar NL, Hatsukami TS, Yuan C: Comparison of symptomatic and asymptomatic atherosclerotic carotid plaque features with in vivo MR imaging. Radiology 240:464-472, 2006.

Sailer J, Rand T, Berg A, Sulzbacher I, Peloschek P, Hölzenbein T, Lammer J: High-resolution 3 T MR microscopy imaging of arterial walls. Cardiovasc. Intervent. Radiol. 29:771-777, 2006.

Savino G, Schoepf JU, Costello P, Sulzbacher I, Pelaschek P, Holzenbein T, Lammer J: 64slice CT angiography reliably detects and excludes significat coronary Artery stenosis on a per-patient but not a per-vessel or persegment basis. Eur. Radiol. 16 (Suppl. 1):303, 2006.

Sawada T, Shite J, Shinke T, Watanabe S, Otake H, Matsumoto D, Tanino Y, Ogasawara D, Paredes OL, Yokoyama M: Relationship between high sensitive $\mathrm{C}$-reactive protein and coronary plaque component in patiens with acute coronary syndrome: Virtual Histology study. J. Cardiol. 48:141-150, 2006.

Schlosser T, Mohrs OK, Magedanz A, Nowak B, Voigtländer T, Schmermund A, Barkhausen J: Non-invasive coronary angiography using 64detector row computed tomography. Eur. Radiol. 16 (Suppl. 1):303, 2006.

Sipahi I, Nicholls SJ, Tuzcu EM: Intravascular ultrasound in the current percutaneous coronary intervention era. Cardiol. Clin. 24:163-173, 2006.

Surmely JF, Nasu K, Fujita H, Terashima M, Matsubara T, Tsuchikane E, Ehara M, Kinoshita Y, Zheng QX, Tanaka N, Katoh O, Suzuki T: Coronary plaque composition of culprit/target lesions according to the clinical presentation: a virtual histology intravascular ultrasound analysis. Eur. Heart J. 27:2939-2944, 2006.

Takayama K, Taoka T, Nakagawa H, Myouchin K, Wada T, Sakamoto M, Fukusumi A, Iwasaki S, Kurokawa S, Kichikawa K: Successful percutaneous transluminal angioplasty and stenting for symptomatic intracranial vertebral artery stenosis using intravascular ultrasound virtual histology. Radiol. Med. (Torino) 25:243-246, 2007.

Tsimikas S, Witztum JL: Shifting the diagnosis and treatment of atherosclerosis to children and young adults. A new paradigm for the 21 st century. J. Am. Coll. Cardiol. 40:2122-2124, 2002. 
Tuzcu EM, Kapadia SR, Tutar E, Ziada KM, Hobbs RE, McCarthy PM, Young JB, Nissen SE: High prevalence of coronary atherosclerosis in asymptomatic teenagers and young adults: evidence from intravascular ultrasound. Circulation 103:2705-2710, 2001.

Valgimigli M, Rodriguez-Granillo GA, Garcia-Garcia HM, Malagutti P, Regar E, de Jaegere P, de Feyter P, Serruys PW: Distance from the ostium as an independent determinant of coronary plaque composition invivo: an intravascular ultrasound study based radiofrequency data analysis in humans. Eur. Heart J. 27:655-663, 2006.

Valgimigli M, Rodriguez-Granillo GA, Garcia-Garcia HM, Vaina S, De Jaegere P, De Feyter P, Serruys PW: Plaque composition in the left main stem mimics the distal but not the proximal tract of the left coronary artery: influence of clinical presentation, length of the left main trunc, lipid profile, and systemic levels of C-reactive protein. J. Am. Coll. Cardiol. 49:23-31, 2007.

Von Birgelen C, Hartmann M: Intravascular ultrasound assessment of coronary atherosclerosis and percutaneous interventions. Minerva Cardioangiol. 52:391-406, 2004.
Von Birgelen C, Li W, Bom N, Serruys PW: Quantitative three-dimensional intravascular ultrasound. Semin. Interv. Cardiol. 2:25-32, 1997.

Warburton L, Gillard J: Functional imaging of carotid atheromatous plaques. J. Neuroimaging 16:293-301, 2006.

Widimsky P, Budesinsky T, Vorac D, Groch L, Zelizko M, Aschermann M, Branny M, St'asek J, Formanek P: Long distance transport for primary angioplasty vs thrombolysis in acute myocardial infarction. Final results of the randomized national multicentre trial PRAGUE-2. Eur. Heart J. 24:94-104, 2003.

Yuan C, Zhang S-X, Polissar NL, Echelard D, Ortiz G, Davis JW, Ellington E, Ferguson MS, Hatsukami TS: Identification of fibrous cap rupture with magnetic resonance imaging is highly associated with recent transient ischemic attack or stroke. Circulation 105:181-185, 2002. 